\title{
The Effect of Region's Socio-Economic and Demographic Charateristic on Covid-19 Confirmed Cases and Deaths
}

\author{
${ }^{* 1}$ Rai, Abyan \\ ${ }^{*}$ Badan Pusat Statistik Kabupaten Sumbawa, West Nusa Tenggara-Indonesia \\ Note: * Indicates corresponding author
}

\begin{tabular}{|c|c|}
\hline ARTICLE DETAILS & \multirow{5}{*}{$\begin{array}{l}\text { Covid-19 pandemic that has hit the world has made almost all } \\
\text { countries limit the mobility of their residents to prevent the } \\
\text { transmission of the Corona virus. Indonesia has also made similar } \\
\text { efforts through Large-Scale Social Restrictions (PSBB). However, } \\
\text { these efforts have not been optimal because they are faced with } \\
\text { obstacles to the uneven distribution of the population and } \\
\text { unfavorable socio-economic conditions. This study aims to } \\
\text { analyze the effect of regional socio-economic and demographic } \\
\text { characteristics on Covid-19 in terms of the number of confirmed } \\
\text { cases and deaths. The analysis was conducted at the provincial } \\
\text { level with a total of } 34 \text { observations and using multiple linear } \\
\text { regression analysis. Socio-economic characteristics are } \\
\text { approximated by the share of the province's GRDP, the } \\
\text { percentage of the poor, and the Human Development Index (HDI). } \\
\text { Demographic characteristics are approximated by population } \\
\text { density and population projections. This study found that the high } \\
\text { confirmed and death cases of Covid-19 were influenced by poor } \\
\text { socio-economic conditions, as well as densely populated } \\
\text { demographic conditions and a high population of an area. The } \\
\text { results of this study also found a significant effect of the provincial } \\
\text { GDRP share and HDI on socio-economic characteristics as well } \\
\text { as population projections on demographic characteristics on } \\
\text { confirmed and Covid-19 deaths cases in Indonesia. }\end{array}$} \\
\hline $\begin{array}{l}\text { Article History } \\
\text { Published Online: publisher use } \\
\text { only }\end{array}$ & \\
\hline $\begin{array}{l}\text { Keywords } \\
\text { Covid-19, coronavirus, Regional } \\
\text { Socio-Economic, Regional } \\
\text { Demographic }\end{array}$ & \\
\hline "Corresponding Author & \\
\hline Email:abyan.rai@bps.go.id & \\
\hline
\end{tabular}

\section{Introduction}

The first case of Covid-19 in Wuhan appeared on December 30, 2019 after the issuance of an "urgent notice on the treatment of pneumonia of unknown case" statement by the Wuhan Municipal Health Committee. The World Health Organization (WHO) explains that Coronaviruses (Cov) are viruses that attack the respiratory system and can cause the common cold to more severe diseases such as Severe Acute Respiratory Syndrome (SARS). The very fast spread of Corona virus has forced several countries to implement a lockdown policy to inhibit the spread (Zahrotunnimah, 2020).

Indonesia has implemented Large-Scale Social Restrictions (PSBB) to prevent crowds and prevent the spread of Corona virus. However, PSBB is still considered unable to prevent the spread of Corona virus given the dense population in several big cities in Indonesia and the economic pressure that forces people to continue their normal activities.

The density that occurs in urban areas makes the population there more at risk of being infected with the Corona virus. Most of the world's population $(55 \%)$ currently live in urban areas to the detriment of their health conditions (UNESCO \& UN-WATER, 2020). Lifestyle of people who live in areas with a large number and density of people tend to be sedentary, poor eating habits, and stress which will eventually lead to obesity, blood pressure, depression, and various other diseases (Kabisch et al., 2017) .

However, several studies have shown that

Faculty of Economics and Business, 
temperature and air pollution are the most problematic for people in densely populated areas (Franco et al., 2017). High air temperature increases susceptibility to new diseases and increases the risk of exacerbating existing diseases related to cardiovascular and respiratory death (Van den Bosch \& Sang, 2017). Air pollution in general and fine particulate matter in particular can cause heart and lung damage. According to Auler et al. (2020), there is evidence that high air temperatures and pollution cause the prevalence and reactions of patients with Severe Acute Respiratory Syndrome Coronavirus 2 (SARS-Cov-2).

Demographic impact on health of the population can be exacerbated by socioeconomic factors. Poverty will have a close relationship with the death rate in a region in general. People with low levels of education tend to visit health services more than people with higher education (Kephart et al., 1998).

Several studies have found the fact that socio-economic has a relationship with respiratory disease. Purwana (1999) stated that socio-economic factors have a major contribution to respiratory tract diseases as a result of the inverse relationship of socioeconomic status and morbidity of acute respiratory infections.

Most of research related to Covid-19 that has been done looks at the impact of Covid-19 addition cases on the economy. Research that explores possible socio-economic and demographic influences on Covid-19 cases has not been widely studied. Therefore, this study aims to analyze the effect of socio-economic and demographic factors on the number of confirmed cases and deaths from Covid-19.

\section{Literature Review}

\subsection{Socio-Economic and Health}

On a macro level, the economic condition of a region can be seen from indicators such as per capita income, poverty level, and Human Development Index (HDI). That three indicators describe the ability of the population in an area to meet basic needs, one of which is health needs.

Poverty is a problem that often arises when a person or group of people is unable to meet basic needs or the minimum limit of a certain standard living. Income level, education, access to goods and services, location, gender, and environmental conditions are interrelated factors in shaping the problem of poverty (Renggapratiwi, 2009). Poverty can also be defined as the inability to meet basic needs including food, clothing, housing, education, and health (Kuncoro, 2003).

Similar to poverty, per capita income also shows the ability of the population in an area to obtain proper health. Per capita income will be in line with the HDI which is formed by three basic dimensions, namely longevity, knowledge, and a decent standard living. Greater the per capita income of population in a region, higher the human development index in that region.

In a declining socio-economic status, all causes of death and all morbidity will increase (Machmud, 2009). The risk of injury, asthma, and hypertension in adolescents increases due to negative behavior in childhood from low socioeconomic status.

\subsection{Demographic and Health}

Science that studies the number, distribution, and structure of the population of an area and the changes that cause these changes, which is births, deaths, migration, and social mobility are called demography (Hauser \& Duncan, 1959). Demographic information describes the organization of population, their size, and composition. Understanding of demographic is important to know the potential and challenges that a region faces from its population.

The number and population growth will be potential if it is balanced with availability of supporting resources. Uncontrolled population growth will cause a population explosion and create an environmental condition with a high population density. The increase in population needs to be followed by an even distribution of the population.

Population density greatly affects quality life of the population life by causing various socioeconomic problems. The existence of these problems will have an impact on the quality of the population life. Objective indicators of quality of life include unemployment rate, crime rate, school participation rate, life expectancy, and health status.

\section{Methodology}

\subsection{Data Source and Research Variables}

This study uses secondary data from several sources. The unit of analysis of this research is all provinces in Indonesia. Total observations from this study were 34 observations. The data was processed using Microsoft Excel and a multivariate analysis processing application created by a Statistics Polytechnic STIS student named Herodes. 


\section{Relation of Region's Socio-Economic and Demographic Charateristic with Covid-19 Confirmed Cases and Deaths}

Socio-economic characteristics are approximated by data on the share of GDRP to total GDRP, percentage of poor people, and human development index. Demographic characteristics are approximated by population density data and population projections. All data are sourced from the Central Bureau of Statistics (BPS). Due to availability, the data used is data at one point in 2020 and is considered representative enough.
The number of confirmed cases and deaths of Covid 19 is sourced from Indonesian Covid-19 Handling Task Force. The data used is data at one point, which is in mid-June 2021.

All of these data will be used as research variables to describe the relationship between socio-economic and demographic characteristics with death and confirmed cases of Covid-19. The following are operational definitions of research variables:

Table 1. Variables and Operational Definitions

\begin{tabular}{|c|c|c|}
\hline Variables & Operational Definition & Unit \\
\hline Confirmed (Y1) & $\begin{array}{l}\text { Number of people confirmed to have been } \\
\text { exposed to Corona virus }\end{array}$ & Number \\
\hline Deaths (Y2) & $\begin{array}{l}\text { Number of people who have been confirmed to } \\
\text { have died due to exposure to Corona virus }\end{array}$ & Number \\
\hline Share GDRP (SE1) & $\begin{array}{l}\text { Contribution of GRDP from a province to the total } \\
\text { GRDP of all provinces in Indonesia }\end{array}$ & Percent \\
\hline $\begin{array}{l}\text { Percentage of Poor People } \\
\text { (SE2) }\end{array}$ & $\begin{array}{l}\text { Comparability between the number of poor people } \\
\text { and the total population converted into percentage }\end{array}$ & Percent \\
\hline $\begin{array}{l}\text { Human Development Index } \\
\text { (SE3) }\end{array}$ & $\begin{array}{l}\text { An index formed to measure development } \\
\text { achievements through the level of income, health, } \\
\text { and education of the population in the region }\end{array}$ & 0 low - 1 high \\
\hline Population Density (D1) & $\begin{array}{c}\text { Number of residents for each square meter of the } \\
\text { area of the province }\end{array}$ & Population/m2 \\
\hline Population Projection (D2) & Estimated population in 2020 & Number \\
\hline
\end{tabular}

\subsection{Method of Analysis}

This study uses a multiple linear regression analysis method between confirmed cases and deaths from Covid-19 with each socio-economic and demographic variable. Multiple linear regression analysis is used in various studies to produce an estimation model as well as examine the effect of the independent variable on the dependent variable. In general, the independent variable from the regression analysis is expressed by $X$ and the dependent variable is expressed by $Y$ (Algifari, 2002).

This study will use two regression equations, namely the equation with the dependent variable of confirmed cases of Covid19 and cases of Covid-19 deaths. The following is the multiple linear regression model used in the study: $\log C C=\beta_{0}+\beta_{1} S E_{1}+\beta_{2} S E_{2}+\beta_{3} S E_{3}+\beta_{4} S E_{5}+\beta_{5} \log D_{2}+\varepsilon \ldots \ldots$
$\log D C=\beta_{0}+\beta_{1} S E_{1}+\beta_{2} S E_{2}+\beta_{3} S E_{3}+\beta_{4} S E_{5}+\beta_{5} \log D_{2}+\varepsilon \ldots$

Where $\beta_{0}$ is constant. Meanwhile, $\beta_{1}, \beta_{2}, \beta_{3}, \beta_{4}, \beta_{5}$ coefficient of each independent variable. $\varepsilon$ is the residual of the equation.

To determine the overall significance of the independent variables, this study used the $F$ test. The null hypothesis of the $F$ test was that none of the independent variables had a statistically significant effect $\left(H_{0}=\beta_{0}, \ldots, \beta_{5}=0\right)$. Here are the $\mathrm{F}$ test statistics:

$F=\frac{\text { Mean Square Regression }}{\text { Mean Square Error }} \sim F_{a, k-1 ; k(n-1)}$

The null hypothesis will be rejected if the test statistic value is $F>F_{a, k-1 ; k(n-1)}$ or 
$\operatorname{Prob}(F)<$ alpha error. If the null hypothesis is rejected, there is at least one independent variable that has a significant effect.

When the $\mathrm{F}$ test rejects the null hypothesis, partial testing is needed to find out which independent variables significantly affect the dependent variable. The partial test that is often used is the t test. The null hypothesis of the t-test is that the $i$-th independent variable has no significant effect $\left(H_{0}=\beta_{i}=0\right)$. Here are the ttest statistics:

$t=\frac{b_{i}}{S b_{i}} \sim t_{\alpha, n-k-1}$

Null hypothesis will be rejected if the test statistic value is $t>t_{\alpha, n-k-1}$ or $\operatorname{Prob}(t)<$ alpha error. If the null hypothesis is rejected, the $i$-th independent variable has a significant effect on the dependent variable.

Goodness of the model is measured by several indicators, one of which is coefficient of determination $\left(R^{2}\right)$. This coefficient measures contribution of independent variable in explaining the variation of dependent variable (Sujana, 2001). The value of the coefficient of determination is in the range of 0 to 1 . The closer to 1 for coefficient value, the better the model used. The following is the equation for calculating coefficient of determination (Sujana, 2001):

$R^{2}=1-\frac{(n-k-1) S_{y}^{2}}{(n-1) S_{y}^{2}}$

where $n$ is the number of observations, $S_{y}{ }^{2}$ is the variance of the dependent variable, and $k$ is the number of independent variables.

\section{Classical Assumption of Linear Regression}

Multiple linear regression analysis using the Ordinary Least Square (OLS) estimation method. Therefore, there are several assumptions that need to be fulfilled. Assumption test aims to provide certainty that the model used has accurate estimation, unbiased, and consistent.

This study uses cross sectional data. So the assumptions that need to be fulfilled are normality, homoscedasticity, and nonmulticollinearity. Nonautocorrelation is more appropriate in research that uses data series.

\section{Normality}

The assumption of normality that is not met will cause the estimate to be biased. The normality test aims to determine the normality of the residuals. This study used the Jarque-Bera normality test. Null hypothesis of the test is that the residuals are normally distributed $\left(H_{0}=\right.$ $\left.\varepsilon_{i} \sim N\left(\mu, \sigma^{2}\right)\right)$. The following are Jarque-Bera test statistics (Gujarati \& Porter, 2008):

$J B=\frac{n}{6}\left(S^{2}+\frac{(K-3)^{2}}{4}\right) \sim \chi^{2}{ }_{2, a}$

$S=\frac{\frac{1}{n} \sum_{i=1}^{n}\left(x_{i}-\bar{x}\right)^{3}}{\left(\frac{1}{n} \sum_{i=1}^{n}\left(x_{i}-\bar{x}\right)^{2}\right)^{3 / 2}}$

$K=\frac{\frac{1}{n} \sum_{i=1}^{n}\left(x_{i}-\bar{x}\right)^{4}}{\left(\frac{1}{n} \sum_{i=1}^{n}\left(x_{i}-\bar{x}\right)^{2}\right)^{2}}$

where $n$ is the number of observations, $S$ is the coefficient of skewness, and $K$ is the coefficient of kurtosis. Null hypothesis will fail to be rejected if the value $J B<\chi_{2, a}^{2}$ or $\operatorname{Prob}(J B)>$ alpha. If the null hypothesis fails to be rejected, the assumption of normality has been fulfilled.

\section{Nonmulticollinearity}

Multicollinearity describes a relatively strong relationship between independent variables and other independent variables. The consequence of multicollinearity is an increase in type II error. In addition, multicollinearity also creates a high $R^{2}$ but none of the independent variables is statistically significant.

To detect multicollinearity, there are several ways, one of which is the Variance Inflation Factor (VIF). A model is said to meet the nonmulticollinearity assumption when the VIF value of each independent variable is less than 10 (Zain, 1995). Here is the formula for VIF:

$V I F=\frac{k}{R^{2}}$

\section{Homoscedasticity}

Homoscedasticity describes the error variance which is constant $\left(E\left(\varepsilon_{i}{ }^{2} \mid X\right)=\sigma^{2}\right)$. The consequence of the unfulfilled homoscedasticity assumption is that the estimation is no longer efficient for both large and small samples even though it is unbiased and consistent. In addition, the heteroscedastic condition makes the estimated variance underestimate or overestimate.

There are several tests to determine if a model can be said to be homoscedastic. One of them is the white test. Null hypothesis of the white test is constant variance or homoscedasticity $\quad\left(H_{0}=\sigma^{2}=\sigma^{2}\right)$. Homoscedastic assumption will be fulfilled when the probability value of white test statistic is

Faculty of Economics and Business, 


\section{Relation of Region's Socio-Economic and Demographic Charateristic with Covid-19 Confirmed}

Cases and Deaths

greater than an alpha error of $5 \%$.

\section{Result and Discussion}

Estimation model using OLS method requires testing the assumptions before being interpreted further. This study examines the existence of the assumptions of normality, homoscedasticity, and non-multicollinearity.

Table 2. Normality and Homoscedasticity Test Results

\begin{tabular}{ccc} 
Dependent Variables & JB & White stat $\left(\chi^{\mathbf{2}}{ }_{\mathbf{2 0}}\right)$ \\
\hline LOG_CC & 2,31 & 25,5 \\
& $(0,3137)$ & $(0,1829)$ \\
LOG_DC & 2,24 & 26,32 \\
& $(0,3249)$ & $(0,1555)$ \\
\hline
\end{tabular}

Source: processed data

In the normality test, the probability value of $\mathrm{JB}$ test statistic in Table 2 for both equations is greater than 0.05 . That is, there is not enough evidence to reject the null hypothesis. Thus, both models in this study have met the assumption of normality at an alpha error level of 5\%.

The value of the white test statistic follows a chi-square distribution with 20 degrees of freedom. In Table 2, the probability value of white test statistic for both equations is greater than 0.05 . There is not enough evidence to reject the null hypothesis of the homoscedasticity test. Thus, the assumption of homoscedasticity for both models in this study has been fulfilled.

Table 3. VIF Value of Independent Variables

\begin{tabular}{cc}
\hline Independent Variables & VIF \\
\hline SEl1 & 5,57 \\
SEI2 & 1,8 \\
SEI3 & 2,3 \\
D1 & 2,97 \\
LOG_D2 & 3,26
\end{tabular}

Table 3 shows the VIF value of each independent variable. Of all the variables, SEI1 has the highest VIF value of 5.57. However, this value is still below 10 . This means that the assumption of nonmulticollinearity in both research models has been met.

With the fulfillment of all classical assumptions for both research models, the consequences for the estimation results are lost. Thus, the estimation results of the two models in this study are already the Best Linear Unbiased Estimator (BLUE). The interpretation of the two BLUE models becomes more accountable.

Table 4 shows the results of equation estimation for dependent variable of confirmed Faculty of Economics and Business, Brawijaya University cases and Covid-19 deaths. In this study, there were three variables that were converted into log form because they had a high range of values compared to other variables, namely confirmed cases, deaths cases, and population projection variables.

Evaluation of the model through the coefficient of determination also shows relatively good results for both models. In the confirmed cases Covid-19 model, the coefficient of determination is 0.849. Meanwhile, the coefficient of determination for the Covid-19 death cases model is 0.867 . This means that more than $80 \%$ of the variation in confirmed cases and Covid-19 death cases can be 
explained by independent variables.

Tabel 4. Hasil Estimasi Model

\begin{tabular}{|c|c|c|c|c|c|c|c|c|}
\hline $\begin{array}{l}\text { Dependent } \\
\text { Variables }\end{array}$ & C & SEl1 & SEI2 & SEI3 & D1 & LOG_D2 & Fstat & $\mathbf{R}^{2}$ \\
\hline & 0,290 & $-0,108$ & 0,002 & $-0,079$ & 0,00006 & 0,471 & 31,682 & \\
\hline LOG_CC & $(-0,9089)$ & $(0,0264)$ & $(0,9191)$ & $(0,0212)$ & $(0,8966)$ & $(0,0033)$ & $(0,0000)$ & 0,849 \\
\hline & $-8,046$ & $-0,106$ & 0,015 & $-0,122$ & 0,00004 & 0,635 & 34,603 & \\
\hline LOG_DC & $(0,0063)$ & $(0,042)$ & $(0,4876)$ & $(0,0015)$ & $(0,3995)$ & $(0,0004)$ & $(0,0000)$ & 0,8607 \\
\hline
\end{tabular}

sumber: data diolah

The $\mathrm{F}$ test statistics shown in Table 4 have a probability value of less than 0.05 in both confirmed cases and deaths cases equations. This means that there is sufficient evidence to reject the null hypothesis of the $\mathrm{F}$ test for both equations at an alpha error level of $5 \%$. The conclusion obtained is that there is at least one independent variable that has a significant effect on confirmed and death cases of Covid-19. So a partial $t$ test needs to be done for both equations.

Table 4 shows that in both the confirmed cases model and the Covid-19 death cases model, the variables SEI1, SEI3, and LOG_D2 have a statistical probability value of t-test less than 0.05 . This means that the share of GDRP, $\mathrm{HDI}$, and changes in population have a significant influence on changes in confirmed and death cases of Covid-19 in Indonesia at an alpha error rate of $5 \%$.

This study aims to find answers to the influence of regional socio-economic and demographic characteristics on confirmed cases and deaths of Covid-19. The results show that there is sufficient evidence to conclude that these two characteristics have an influence on changes in confirmed cases and deaths of Covid-19 in Indonesia.

Table 4 shows that socio-economic characteristics have a significant negative effect through the share of GDRP and HDI on changes in confirmed cases and death cases of Covid-19 in Indonesia. For every one percent increase in the provincial GDRP share, there will be a decrease change of $0.108 \%$ confirmed cases and $0.106 \%$ Covid- 19 death cases in Indonesia. This is in line with the research of Marmot et al. (2020) which found a strong correlation between poor socio-economic conditions and the high death rate from Covid-19 in the UK. In addition, Das et al. (2020) also found a correlation between poor environmental conditions and the high transmission of Covid-19 in Kolkata.

The percentage of poor people on socioeconomic characteristics has a positive influence on changes in confirmed cases and death cases of Covid-19 in Indonesia. However, the effect given is not statistically significant. The weak influence of the percentage of poor people because the data used in the study are very general, namely data at the provincial level. Different things might happen if the next research uses data at the district/city level or even at the village level.

On demographic characteristics, population density and changes in population projections have a positive influence on changes in the number of confirmed cases and deaths of Covid19. However, population density does not have a significant effect. This is caused by variations in population density data which is very high in range. Similar to the variable percentage of poor people, data at the provincial level is also one of the causes of this insignificant effect.

A significant positive effect occurs between changes in projected population numbers and changes in confirmed and death cases of Covid19. For every $1 \%$ increase change in the projected population, an increase in change also occurs in confirmed cases by $0.471 \%$ and in deaths cases by $0.635 \%$. This is in line with the research conducted by Kodera et al. (2020) in Japan and Mansour et al. (2021) in Oman who concluded that urban demographic characteristics such as the large number of residents are related to Covid-19. The bigger the population, the bigger the number of confirmed 


\section{Relation of Region's Socio-Economic and Demographic Charateristic with Covid-19 Confirmed Cases and Deaths}

cases and deaths of Covid-19.

As agreed by all members of the United Nations in 2015, ensuring the health and wellbeing of all human beings is one of the goals of the agenda for sustainable development. The results found in this study are mostly related to objectives 3.3, 3.4, and 3.9 on epidemics, diseases, and air pollution. The evidence found in this study can be used as a basis for making decisions about population distribution and socio-economic improvement to obtain better health and well-being and reduce health carerelated costs for the community (Kondo et al., 2020).

\section{Conclusion}

This study found several interesting results based on the initial goal, namely to analyze the influence of socio-economic and demographic characteristics on confirmed cases and deaths of Covid-19. In general, socio-economic and demographic characteristics have a significant influence on confirmed and death cases of Covid-19 at an alpha error level of 5\%.

In general, the results of the study found that poor socio-economic characteristics will also have a bad influence on confirmed and death cases of Covid-19 in Indonesia. The share of GDRP and HDI has a significant negative effect on confirmed and death cases of Covid-19 at an alpha error rate of $5 \%$. The percentage of poor people has a positive but not statistically significant effect.

This study also found that the denser the population in an area, the more the number of people infected and died from Covid-19. However, population density does not have a statistically significant effect on confirmed and death cases of Covid-19 in this study. The projected population at the provincial level shows a significant effect in line with the number of confirmed cases and deaths of Covid-19 at an alpha error level of $5 \%$.

This research is expected to be a form of contribution to knowledge about Covid-19 and the impact of regional socio-economic and demographic characteristics on health. This research can also be used as a basis for making policies related to preventing the transmission of Covid-19.

\section{References}

Algifari. (2002). Analisa Regresi Teori, Kasus dan Solusi, Edisi 2. Yogyakarta: BPFE.

Faculty of Economics and Business,

Brawijaya University
Auler, A.C., Cassaro, F.A.M., da Silva, V.O., \& Pires, L.F. (2020). Evidence That High Tempratures and Intermediate Relative Humidity Might Favor the Spread od Covid-19 in Tropical Climate: A Case Study for the Most Affected Brazilian Cities. The Science of the Total Environment. https://doi.org/10.1016/j. scitotenv.2020.139090.

Das, A., Ghosh, S., Das, K., Basu, T., Dutta, I., \& Das, M. (2021). Living Environment Matters: Unravelling the Spatial Clustering of Covid-19 Hotspots in Kolkata Megacity, India. Sustainable Cities and Society.

Franco, L.S., Shanahan, D.F., \& Fuller, R.A. (2017). A Review of the Benefits of Nature Expriences: More than meets the eye. International Journal of Environemental Research and Public Health. 14(8), $864 . \quad$ https://doi.org/ 10.3390/ijerph14080864.

Gujarati, D.N., \& Porter, D.C. (2008). Basic Econometrics Fifth Edition. New York: McGraw-Hill, Inc.

Hauser, P.M., \& Duncan, O.D. (1959). The Study of Population: An Inventory and Appraisal. Chicago: University of Chicago Press.

Kabisch, N., Haase, D., \& van den Bosch, M. (2016). Adding Natural Areas to Social Indicators of Intra-Urban Health Inequalities Among Children: A Case Study From Berlin, Germany. International Journal of Environmental Research and Public Health. 13(8), 783. https://doi.org/10.3390/ijerph13080783.

Kephart, G., Vince, S.T., \& David, R.M. (1998). Socioeconomic differences in the use of physician services in Nova Scotia. American Journal of Public Health.

Kodera, S., Rashed, E., \& Hirata, A. (2020). Correlation Between Covid-19 Morbidity and Mortality Rates in Japan and Local Population Density, Temperature, and Absolute Humidity. International Journal of Environmental Research and Public Health. 17(15), 5477. https://doi.org/10. 3390 /ijerph17155477.

Kondo, M.C., Mueller, N., Locke, D.H., Roman, L.A., Rojas-Rueda, D., Schinasi, L.H., Nieuwenhuijsen, M.J. (2020). Health Impact Assessment of Philadelphia's 2025 Tree Canopy Cover Goal. The Lancet Planetary Health. 
https://doi.org/10.1016/S2542-

5196(20)30058-9.

Kuncoro, M. (2003). Metode Riset Untuk Bisnis dan Ekonomi. Jakarta: Erlangga.

Machmud, R. (2009). Pengaruh Kemiskinan Keluarga Pada Kejadian Pneumonia Balita di Indonesia. Kesmas: Jurnal Kesehatan Masyarakat Nasional (National Public Health Journal). 4(1), 36-41.

Mansour, S., Kindi, A.A., Al-Said, A., Al-Said, A., \& Atkinson, P. (2021). Sociodemographic Determinants of Covid-19 Incidence Rates in Oman: Geospatial Modelling Using Multiscale Geographically Weighted Regression (MGWR). Sustainable Cities and Society. https://doi.org/10.1016/i.scs.20 20.102627.

Marmot, M., Allen, J., Goldbatt, P., Herd, E., \& Morrison, J. (2020). Build Back Fairer: The Covid-19 Marmot Review The Pandemic, Socio-Economic, and Health Inequalities in England. London: Institute of Health Equity.

Purwana, R. (1999). Partikulat Rumah Sebagai Faktor Risiko Gangguan Pernapasan Anak Balita (Penelitian di Pekojan, Jakarta). Fakultas Kesehatan Masyarakat, Universitas Indonesia [Disertasi].

Renggapraptiwi, A. (2009). Kemiskinan Dalam Perkembangan Kota Semarang: Karakteristik dan Respon Kebijakan. Semarang: Universitas Diponegoro.

Sujana. (2001). Metode Stastik. Bandung: Tarsito.

UNESCO, \& UN-WATER. (2020). United Nations World Water Development Report 2020: Water and Climate Change. Retrivied June 20th 2021, from www.unwater.org/publications/worldwater-development-report-2020/.

Van den Bosch, M., \& Sang, A.O. (2017). Urban Natural Environments as Nature-Based Solutions for Improved Public Health - A Systematic Review of Reviews. Environmental Research. https://doi.org /10.1016/i,envres.2015.05.040.

Zahrotunnimah. (2020). Langkah Taktis Pemerintah Daerah Dalam Pencegahan Virus Corona Covid-19 di Indonesia. Jurnal Sosial dan Budaya Syar'i. 7(3), 248.

Zain, S. (1995). Ekonometrika Dasar. Jakarta: Erlangga.

Faculty of Economics and Business,

Brawijaya University 